\title{
Activation of phagocytosis by immune checkpoint blockade
}

\author{
Chia-Wei $\mathrm{Li}^{1}$, Yun-Ju Lai ${ }^{2}$, Jennifer L. Hsu ${ }^{1}$, Mien-Chie Hung $(\bowtie)^{1}$ \\ ${ }^{1}$ Department of Molecular and Cellular Oncology, The University of Texas MD Anderson Cancer Center, Houston, TX 77030, USA; \\ ${ }^{2}$ Department of Neurology, McGovern Medical School, The University of Texas Health Science Center at Houston, Houston, TX 77030, USA \\ (C) The Author(s) 2018. This article is published with open access at link.springer.com and journal.hep.com.cn
}

\begin{abstract}
Inhibition of macrophage-mediated phagocytosis has emerged as an essential mechanism for tumor immune evasion. One mechanism inhibiting the innate response is the presence of the macrophage inhibitory molecule, signal regulatory protein- $\alpha(\mathrm{SIRP} \alpha)$, on tumor-associated macrophages (TAMs) and its cognate ligand cluster of differentiation 47 (CD47) on tumor cells in the tumor microenvironment. On the basis of a recently discovered programmed death protein 1 (PD-1) in TAMs, we discuss the potential inhibitory receptors that possess new functions beyond $T$ cell exhaustion in this review. As more and more immune receptors are found to be expressed on TAMs, the corresponding therapies may also stimulate macrophages for phagocytosis and thereby provide extra anti-tumor benefits in cancer therapy. Therefore, identification of biomarkers and combinatorial therapeutic strategies, have the potential to improve the efficacy and safety profiles of current immunotherapies.
\end{abstract}

Keywords CD47; PD-1; PD-L1; immunotherapy; TAM; phagocytosis; macrophage

\section{Introduction}

The field of immuno-oncology has dramatically reshaped the landscape of cancer therapy since the development of antibodies that block immune checkpoint proteins, which activate anti-tumor immunity by enhancing T cell cytolytic activity [1]. To date, dozens of immune checkpoint blockades have been developed for clinical trials in treating leukemia, lymphoma, and solid tumors [2,3]. In particular, antibodies targeting immune checkpoint protein programmed death protein 1 (PD-1) and programmed death ligand 1 (PD-L1) have been approved by the Food and Drug Administration (FDA) to treat 25 types of cancers in over 120000 patients [4]. Despite their clinical success in producing durable responses, the overall response rate of immunotherapy is $15 \%-20 \%$ [5]. Many combinatorial strategies were thus rationally designed and tested in the clinic in attempt to enhance the therapeutic outcome of cancers [3]. Moreover, issues such as missing targets, intrinsic/acquired resistance, hyper-progressive diseases, the lack of reliable biomarkers, autoimmune diseases, and neurotoxicity, have now become the new challenges awaiting further investigation [6-8]. Therefore, furthering our understanding of the mechanisms under-

Received April 6, 2018; accepted July 4, 2018

Correspondence: Mien-Chie Hung, mhung@mdanderson.org lying cell-cell interaction may help identify responsive cohorts of patients and enhance the response rate of immunotherapy. Immune defense is typically divided into two categories: innate and adaptive response. Innate immunity refers to the nonspecific recognition that reacts immediately after antigen exposure whereas adaptive immunity involves more complex processes, including antigen recognition and $\mathrm{T}$ cell activation in order to eliminate the specific antigen. The field of cancer immunotherapy has primarily focused on the molecular interaction between cancer and the effector $\mathrm{T}$ cells in the tumor microenvironment; however, targeting the signaling that allow cluster of differentiation 47 (CD47)-mediated inhibition of macrophage engulfment has emerged as a new type of immunotherapy strategy [9]. Virtually expressed in all types of cancers, CD47 is a transmembrane molecule that engages with signal regulatory protein- $\alpha$ $(\operatorname{SIRP} \alpha)$ on the dendritic cells and macrophages [10]. Through overexpression of CD47 on their surface, cancer cells defend themselves against phagocytosis by macrophages. High expression of CD47 has been shown to correlate with poorer disease survival in many cancer types, including acute myeloid leukemia [11], breast carcinoma [12,13], esophageal carcinoma [14], and gastric cancer [15]. Low expression of CD47 is correlated with positive disease outcome of ovarian carcinoma [16]. Indeed, pathological evidence has consistently shown that expression of CD47 is a pro-tumorigenic factor. In a therapeutic setting, monoclonal antibodies that block the 
interaction between CD47 and SIRP $\alpha$ robustly reawakens the innate immunity in mice [11]. Furthermore, combining anti-CD47 with anti-PD-1 induced stronger antitumor immunity than anti-CD47 alone [17]. Currently, ten clinical trials are underway to test the efficacy of antiCD47 agents (Hu5F9-G4, TTI-621, or CC-90002) as monotherapy or in combination with chemotherapy or target therapy to treat acute myeloid leukemia, colorectal cancer, solid tumor, and non-Hodgkin's lymphoma [18]. Because CD47 is also expressed in normal tissues, toxicity has been observed in the pre-clinical study, but the adverse events are manageable [11]. A multiple dose escalation study of Hu5F9-G4, a humanized monoclonal antibody against the human $\mathrm{CD} 47$, for advanced solid malignancy or lymphoma (NCT02216409) indicated that it was well tolerated. Mild anemia was observed in some patients but can be managed without blood transfusion. Together, targeting innate immune checkpoint CD47 is a safe and excellent strategy as a monotherapy or in combination with other anti-cancer therapy [18]. Multiple clinical trials targeting macrophage have been initiated since 2014 for the treatment of several types of cancers [18].

Similar to CD47-SPIR $\alpha$, Barkal et al. identified an essential role of major histocompatibility complex (MHC) class I in controlling the phagocytic function of macrophages through the expression of $\beta_{2}$-microglobulin ( $\left.\beta 2 \mathrm{M}\right)$ by cancer cells. They found that leukocyte immunoglobulin-like receptor B1 (LILRB1) on the surface of TAMs binds to a portion of MHC-I on cancer cells, which inhibited the ability of macrophages to engulf the cancer cells. Blocking both MHC-I and LILRB1 pathways stimulated macrophage engulfment in vitro and in vivo and significantly slowed tumor growth in mice [19].

It was previously thought that PD-1 is expressed primarily on $\mathrm{T}$ cells and induces $\mathrm{T}$ cell exhaustion via the single immunoreceptor tyrosine-based inhibitory motif (ITIM) within its cytoplasmic tail [20]. When engaged with cancer cell PD-L1, the ITIM domain of PD-1 activates SHP2 to inhibit ZAP70 resulting in suppressing the activity of CD3/CD28 $T$ cell receptor [21]. However, a recent study published in Nature by Gordon et al. reported the identification of PD-1-expressing TAMs [17]. In a mouse CT26 syngeneic mouse model, the authors found that $70 \%$ of TAMs express PD-1 on the cell surface compared with $2 \%$ and $1 \%$ of that in the blood and spleen macrophages, respectively [17]. In the human colorectal cancer samples, the levels of PD- $1^{+}$TAMs are positively correlated with tumor malignancy. Functionally, the authors further demonstrated that PD $-1^{+}$TAMs are less capable of carrying out phagocytosis by (1) ex vivo phagocytosis assay using cocultures FACS-sorted PD- $1^{+}$ and PD- $1^{-}$TAMs from CT26 tumors with $\mathrm{GFP}^{+}$Staphylococcus aureus bioparticles; (2) in vivo phagocytosis analysis using immunocompromised BALB/c Rag2 ${ }^{-1-}$ $\gamma \mathrm{c}^{-/-}$mice engrafted with PD-L1-knockout CT26/YFP ${ }^{+}$ cells. The results from these two models suggested that tumor cells showing loss of PD-1/PD-L1 axis are phagocytized.

In addition, Gordon et al. further performed a bone marrow transplantation experiment to demonstrate the origin of the macrophage-induced tumor cell phagocytosis. To do this, donor bone marrow from $\mathrm{RFP}^{+} \mathrm{C} 57 \mathrm{BL} / 6$ mice was engrafted into irradiated host $\mathrm{GFP}^{+} \mathrm{C} 57 \mathrm{BL} / 6$ mice, which were then inoculated with MC38 colon cancer cells to the mice. After three weeks, they found that significantly higher fractions of PD- $1^{+}$TAMs were derived from donor $\mathrm{RFP}^{+}$bone marrow, suggesting that $\mathrm{PD}-1^{+}$TAMs originated from circulating leukocytes but not from resident immune cells in the host. They also showed that the combined therapy of HAC (anti-human PD-L1 small protein) and anti-CD47 enhanced anti-tumor efficacy and survival rate in a human $\mathrm{DLD} / \mathrm{GFP}^{+}$colon cancer xenograft mouse model with NSG mice. These wellexecuted studies provided important molecular insights into a potentially effective therapeutic strategy by elevating phagocytosis against cancers by targeting the PD-1 pathway with PD-L1 protein or anti-PD-1 and sensitizing CT26 cells to anti-CD47 therapy [17].

\section{An old dog with a new trick}

The study by Gordon et al. identifying a new mechanism of anti-PD-1, which can enhance the engulfment of cancer cells through TAM activation, has opened a new avenue toward the improvement of immunotherapy. Their findings suggested that the interaction between PD-L1 on tumor cells and PD-1 on PD-1 ${ }^{+}$TAM produces a "don't-eat-me" signal that inhibits macrophage-mediated phagocytosis. Because macrophage-related immunity represents an innate immune response, this may partially explain why the efficacy of anti-PD-1 is more efficient than other types of immunotherapies as it can stimulate the phagocytosis of the cancer cells (Fig. 1). However, it remains unclear how much of the anti-PD-1 efficacy is attributed to phagocytosis. If the anti-PD-1-mediated antitumor effect requires phagocytosis, tumors with more TAM may respond better to anti-PD-1. In addition, proinflammatory cytokines or CD47 could serve as predictive markers for the anti-PD-1 therapy. It is likely that the innate immune response of TAMs induces phagocytosis of a particular type of cancer cells that share similar features to foreign pathogens. The engulfment of these cells by TAMs will (1) increase secretion of cytokines to attack $\mathrm{T}$ cell infiltration and subsequently (2) present tumor antigens for $\mathrm{T}$ cell activation.

Interestingly, the pro-inflammatory cytokine, IFN $\gamma$, which is secreted by $\mathrm{CD} 8^{+} \mathrm{T}$ cells, induces cytotoxicity against cancer cells. On the other hand, cancer cells are known to express high levels of PD-L1 on the cell surface 


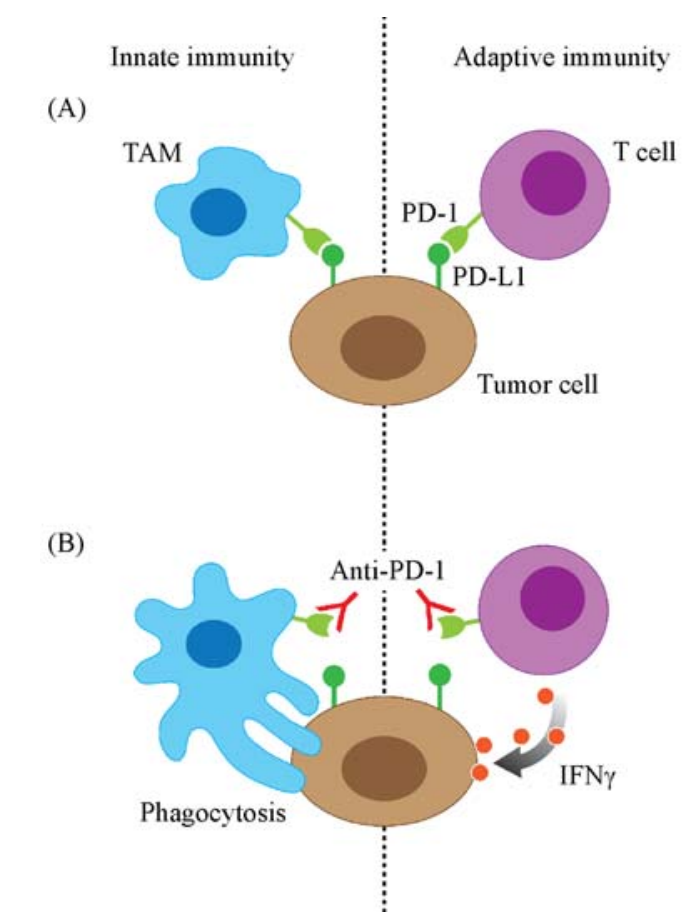

Fig. 1 Anti-PD-1 therapy induces both $\mathrm{TAMs}$ and $\mathrm{CD}^{+} \mathrm{T}$ cell activity. (A) The expression of PD-1 on the tumor-associated macrophages (TAMs) and $\mathrm{T}$ cell inhibits antitumor immunity. (B) PD-1 antibody induces innate immunity by TAM phagocytosis and adaptive immunity by $\mathrm{T}$ cell cytolytic activity.

to suppress the effector T cells via PD-1 [22]. This negative feedback regulation allows cancer cells to escape immune surveillance [23]. Likewise, a recent study suggested that another pro-inflammatory cytokine, $\mathrm{TNF} \alpha$, which is secreted by macrophages, induces stabilization of PD-L1 on cancer cells through COP9 signalosome subunit 5 (CSN5)-mediated de-ubiquitination [24]. If TNF $\alpha$ stabilizes cancer cell PD-L1 to engage with PD- $1^{+}$TAMs, the activated macrophages are subsequently inhibited. Therefore, the TNF $\alpha$-PD-L1-PD-1 axis may be a new negative feedback loop that occurs between TAMs and cancer cells.

\section{Cooperation between innate and adaptive immunity}

The findings by Gordon et al. also point to an important concept of the crosstalk between innate immune response and adaptive immunity (Fig. 1). Innate immunity represents a nonspecific defense mechanism that comes into play immediately when a foreign antigen appears in the body. Adaptive immunity refers to the antigen-specific immune response that requires more complex immune reaction for activation. Although the two immune systems crosstalk, it is not yet clear how they work with one another in the tumor microenvironment. To date, some studies have shown that $\mathrm{CD} 8^{+} \mathrm{T}$ cells play a critical role in mouse antiCD47 blockade-induced tumor reduction even though the target is not directly on the T cells [25]. Depletion of CD8 ${ }^{+}$ $\mathrm{T}$ cells diminishes the anti-tumor activity of mouse CD47 antibody in a syngeneic mouse model [25,26]. Moreover, IFN $\gamma$ was significantly upregulated when mice treated with anti-CD47 [9], suggesting that while TAMs are engulfing cancer cells, the antigen presenting function of the macrophages induces $\mathrm{CD} 8^{+} \mathrm{T}$ cells to further eradicate cancer cells [18]. Similar to the notion, the presence of TAMs is critical for anti-PD-1 therapy. Because TAMs present tumor antigen for T cell activation, the more TAMs are present in the tumor area, the better the therapeutic outcome of anti-PD-1 [6]. On the basis of the findings by Gordon et al., the presence of both innate and adaptive immune cells is critical for the anti-tumor activity. Molecules that are expressed on both TAMs and T cells may be useful to induce two types of the immune response against tumor progression.

\section{TAM, a two-edged sword}

TAMs, mostly composed of M2 type macrophages, have been shown to provide a favorable microenvironment for tumor progression, angiogenesis, metastasis, and drug resistance in the hypoxic environment [27]. TAMs can suppress the $\mathrm{CD} 8^{+} \mathrm{T}$ cell immune response against cancer by directly interacting with T cells via the PD-1 pathway or by secreting immunosuppressive factors, e.g., IL-10 and TGF- $\beta[28,29]$. Clinicopathological studies often link the expression of TAMs with poorer disease outcomes [30,31]. The study by Gordon et al. showed PD-1- TAMs can engulf cancer cells, adding new insight into the current anti-PD-1 therapy. However, some concerns still exist regarding the oncogenic function of TAMs. First, it remains to be determined whether activation of TAMs by anti-PD-1 for phagocytosis also promotes tumor aggressiveness or creates apoptotic insensitive tumor cells that escape $\mathrm{T}$ cells surveillance. In this regard, colony-stimulating factor 1 receptor (CSF-1R)-targeted therapy, such as RG7155 or PLX339, may be an alternative to reduce TAM polarization $[32,33]$. In addition, since TAMs produce the chemokine CCL22 to attract regulatory $\mathrm{T}$ cells and myeloid-derived suppressor cells to the tumor site, neutralization of CCL22 may reduce this potential adverse effect. If TAMs engulf cancer cells before its oncogenic activity, triggering TAMs self-apoptosis after phagocytosis can overcome the risk of TAMs activation. Thus far, more and more subsets of immunosuppressive cells have been identified, and are shown to be regulated in part by TAMs [34]. Harnessing TAMs-mediated tumorigenic phenotype may be more complicated than we expected. 


\section{Other potential "don't-eat-me" signals}

Given the importance of TAMs and T cells' immune reaction, we searched for other known $\mathrm{T}$ cell immune receptors that are also expressed on the macrophages and TAMs. Ideally, for molecules expressed on both T cells and TAMs, their therapeutic agents should be those that can stimulate both TAMs and T cell activation. According to the current published studies, we summarized 14 groups of immune checkpoints in Table 1. The PD-L1-PD-1 (Group 1), CD47-SIRP $\alpha$ (Group 6), and MHCI-LILRB1 (Group 8) are known to induce the "don't-eat-me" signals that have been described above. Inhibition of these signaling can enhance both innate and adaptive immunity, so in-depth analysis should first focus on these three groups as their therapeutic agents may share similar efficacy and response profile. PVR-TIGIT (Group 4), B7-1/2 (Group 5), and OX40L-OX40 (Group 12), on the other hand, are expressed only on macrophages but not TAMs; thus, it is unclear whether they are involved in the function of phagocytosis. If so, how those activated macrophages migrate to the tumor area is an important question to be addressed. As for the other eight groups from the list, they are expressed on the TAMs, which is present in the tumor microenvironment to quickly act on tumor cells once activated. Importantly, some of their targeting agents are available and/or currently being evaluated in the clinical trials, e.g., anti-CTLA4, anti-VISTA, anti-TIM3, and antiCD40, among others. It is therefore of interest to know whether those responders experience innate immune reactions during the treatment. Markers such as serum levels of CD163 (sCD163), the presence of $\mathrm{CD}^{+} 8^{+}$or

Table 1 Immune checkpoints expression across three cell types categorized into different receptor-ligand pair groups

\begin{tabular}{|c|c|c|c|c|c|c|c|}
\hline Group & Macrophages & T cells & Tumors & Suppressive/stimulatory & Localization & Targeted drug & References \\
\hline \multirow[t]{5}{*}{$\overline{1}$} & PD-1 (CD279) & & PD-L1 & Suppressive & TAMs & Available & {$[17]$} \\
\hline & & PD-1 & PD-L1 & Suppressive & & & {$[42]$} \\
\hline & $\begin{array}{l}\text { PD-L1 (B7-H1; } \\
\text { CD274), PD-L2 } \\
\text { (CD273) }\end{array}$ & & & & & & {$[43]$} \\
\hline & PD-L1 & PD-1 & & Suppressive & TAMs & & {$[44]$} \\
\hline & $\mathrm{RGMb}$ & & PD-L2 & Suppressive & TAMs & & {$[45]$} \\
\hline \multirow[t]{2}{*}{2} & B7-H4 & & & & TAMs & Available & {$[46]$} \\
\hline & & & B7-H4 & Stimulatory & & & {$[47]$} \\
\hline \multirow[t]{2}{*}{3} & TIM3 & GAL9 & & Suppressive & TAMs & Available & {$[48]$} \\
\hline & & TIM3 & GAL9 & Suppressive & & & [49] \\
\hline \multirow[t]{5}{*}{4} & PVR (CD155) & TIGIT & & Suppressive & & Available & {$[50]$} \\
\hline & & TIGIT & PVR & Suppressive & & & {$[51]$} \\
\hline & & $\mathrm{CD} 226$ & PVR & Stimulatory & & & {$[52]$} \\
\hline & PVR (CD155) & $\mathrm{CD} 226$ & & Stimulatory & & & {$[53]$} \\
\hline & & CD112R & CD112 & Suppressive & & & {$[54]$} \\
\hline \multirow[t]{3}{*}{5} & $\begin{array}{r}\text { B7-1 (CD80), } \\
\text { B7-2 (CD86) }\end{array}$ & & & & & Available & {$[55]$} \\
\hline & & $\mathrm{CD} 28$ & B7-1, B7-2 & Stimulatory & & & {$[56]$} \\
\hline & & CTLA-4 & B7-1, B7-2 & Suppressive & & & \\
\hline 6 & $\operatorname{SIRP} \alpha$ & & $\mathrm{CD} 47$ & Suppressive & TAMs & Available & {$[57]$} \\
\hline 7 & 4-1BBL (CD137L) & 4-1BB (CD137) & 4-1BBL & Stimulatory & TAMs & Available & {$[58]$} \\
\hline 8 & LILRB1 & & MHC I & Suppressive & TAMs & $\mathrm{N} / \mathrm{A}$ & [19] \\
\hline 9 & LRP1 & & CRT & Stimulatory & TAMs & N/A & [59] \\
\hline 10 & RAGE & & S100 & Suppressive & TAMs & N/A & {$[60]$} \\
\hline \multirow[t]{2}{*}{11} & $\mathrm{CD} 40$ & & $\mathrm{CD} 40 \mathrm{~L}$ & Stimulatory & TAMs & N/A & {$[61]$} \\
\hline & & $\mathrm{CD} 40$ & $\mathrm{CD} 40 \mathrm{~L}$ & & & & {$[62]$} \\
\hline \multirow[t]{2}{*}{12} & OX40L & OX40 & & Stimulatory & & Available & {$[63]$} \\
\hline & & OX40 & OX40L & & & & {$[64]$} \\
\hline 13 & ICOSL & ICOS & ICOSL & Stimulatory & TAMs & Available & {$[65]$} \\
\hline \multirow[t]{2}{*}{14} & VISTA & & & & TAMs & Available & {$[66,67]$} \\
\hline & & VISTA & VISTA-R & & & & \\
\hline
\end{tabular}

N/A, not available. 
$\mathrm{CD} 63^{+} \mathrm{CD}^{204^{+}}$macrophages in the tumor region can be used as indicator of macrophage or TAM activation following drug treatment [35].

\section{Future prospective}

Uncontrolled outgrow by signaling deregulation is a hallmark of cancer. For many years, therapies targeting signaling pathway or protein activities have been promising strategies for many types of cancers. As a new type cancer therapy, immunotherapy, which enhances our immunity to fight against cancer, has been shown to be a relatively safe and tolerable choice. Thus, combination immunotherapy with chemotherapy or targeted therapy is an appealing strategy for combating the heterogeneity of tumors. To date, several therapeutic strategies have been successfully developed based on the understanding of the regulatory mechanism of immune checkpoints. Through the understanding of molecular regulation of immune receptors, TAM-mediated tumorigenesis may be limited.

In respond to IFN $\gamma$, cancer cells express PD-L1 to launch a feedback inhibition on $\mathrm{T}$ cells. Despite the understanding on the transcriptional regulation, posttranslational modification of PD-L1 and its impact on cancer immunosuppression has emerged as an important mechanism for immune evasion. Based on the mechanisms underlying the post-translational regulation of PD-L1, many combinatorial strategies can be rationally designed with strong clinical value. Through EGFR and NF- $\kappa B$ signaling, we have previously reported several safe and effective combinations, such as gefitinib plus anti-PD-1 [36], curcumin plus anti-CTLA4 [24] and PARP-1 plus anti-PD-L1 [37] that may be worthy of being tested in clinical trials. Moreover, a study by Zhang et al. showed that stabilization of PD-L1 by CDK4/6 inhibitor sensitizes CT26 to anti-PD-1 [38]. CMTM6 [CKLF (chemokine-like factor)-like MARVEL transmembrane domain containing family member 6] maintains the membrane PD-L1 protein turn over, thereby reducing anti-tumor immunity $[39,40]$. The discovery of PD-L1 glycosylation also reveals that Nlinked glycosylation protects proteins from GSK3 $\beta$ mediated degradation [36]. Monoclonal antibody targeting N192 and N200 glycosylation of PD-L1 can internalize PD-L1, which serves as a potential candidate for antibodydrug conjugate [41]. In this regard, identifying small molecule inhibitors that can effectively block posttranslational modification events may improve the effectiveness of current immune checkpoint blockades.

\section{Conclusions}

The discovery of TAM PD- $1^{+}$by Gordon et al. shed new light on the inhibitory function of PD-1 beyond its role in T cell exhaustion. In addition to rejuvenating the cytotoxic $\mathrm{T}$ cell activity, anti-PD-1 therapy can also now stimulate TAMs to engulf cancer cells. The findings of that study suggested that coordination of innate and adaptive immune response is vital for anti-tumor immunity. Here, we identify several other immune receptors that are expressed on both TAMs and T cells. Therapeutic agents against these targets may induce a dual immune response and broaden the patient population for immunotherapy.

\section{Acknowledgements}

We thank Dr. Jung-Mao Hsu for assisting with model illustration. This work was funded in part by the following: National Institutes of Health (No. CCSG CA016672); Cancer Prevention \& Research Institutes of Texas (Nos. DP150052 and RP160710); National Breast Cancer Foundation, Inc.; Breast Cancer Research Foundation (No. BCRF-17-069); Patel Memorial Breast Cancer Endowment Fund; Ministry of Health and Welfare, China Medical University Hospital Cancer Research Center of Excellence (Nos. MOHW107-TDU-B212-114024 and MOHW107-TDU-B-212-112015); and Center for Biological Pathways. In memoriam, Mrs. Serena Lin-Guo, for her courageous fight against cancer.

\section{Compliance with ethics guidelines}

Chia-Wei Li, Yun-Ju Lai, Jennifer L. Hsu, and Mien-Chie Hung declare no conflict of interest. This article does not contain any studies with human or animal subjects. This manuscript is a review article and does not involve a research protocol requiring approval by the relevant institutional review board or ethics committee.

Open Access This article is distributed under the terms of the Creative Commons Attribution 4.0 International License (http:// creativecommons.org/licenses/by/4.0/), which permits unrestricted use, distribution, and reproduction in any medium, provided the appropriate credit is given to the original author(s) and the source, and a link is provided to the Creative Commons license, which indicates if changes are made.

\section{References}

1. Pardoll DM. The blockade of immune checkpoints in cancer immunotherapy. Nat Rev Cancer 2012; 12(4): 252-264

2. Morrissey KM, Yuraszeck TM, Li CC, Zhang Y, Kasichayanula S. Immunotherapy and novel combinations in oncology: current landscape, challenges, and opportunities. Clin Transl Sci 2016; 9 (2): 89-104

3. Li CW, Lim SO, Hsu JL, Hung MC. Rational combination of immunotherapy for triple negative breast cancer treatment. Chin Clin Oncol 2017; 6(5): 54

4. Iwai Y, Hamanishi J, Chamoto K, Honjo T. Cancer immunotherapies targeting the PD-1 signaling pathway. J Biomed Sci 2017; 24 (1): 26 
5. Alexander W. The checkpoint immunotherapy revolution: what started as a trickle has become a flood, despite some daunting adverse effects; new drugs, indications, and combinations continue to emerge. P T 2016; 41(3):185-191

6. Zou W, Wolchok JD, Chen L. PD-L1 (B7-H1) and PD-1 pathway blockade for cancer therapy: mechanisms, response biomarkers, and combinations. Sci Transl Med 2016; 8(328): 328rv4

7. Sharma P, Hu-Lieskovan S, Wargo JA, Ribas A. Primary, adaptive, and acquired resistance to cancer immunotherapy. Cell 2017; 168(4): 707-723

8. Spain L, Walls G, Julve M, O’Meara K, Schmid T, Kalaitzaki E, Turajlic S, Gore M, Rees J, Larkin J. Neurotoxicity from immunecheckpoint inhibition in the treatment of melanoma: a single centre experience and review of the literature. Ann Oncol 2017; 28(2): 377-385

9. Jaiswal S, Jamieson CH, Pang WW, Park CY, Chao MP, Majeti R, Traver D, van Rooijen N, Weissman IL. CD47 is upregulated on circulating hematopoietic stem cells and leukemia cells to avoid phagocytosis. Cell 2009; 138(2): 271-285

10. Jiang P, Lagenaur CF, Narayanan V. Integrin-associated protein is a ligand for the P84 neural adhesion molecule. J Biol Chem 1999; 274(2): 559-562

11. Majeti R, Chao MP, Alizadeh AA, Pang WW, Jaiswal S, Gibbs KD Jr, van Rooijen N, Weissman IL. CD47 is an adverse prognostic factor and therapeutic antibody target on human acute myeloid leukemia stem cells. Cell 2009; 138(2): 286-299

12. Baccelli I, Stenzinger A, Vogel V, Pfitzner BM, Klein C, Wallwiener M, Scharpff M, Saini M, Holland-Letz T, Sinn HP, Schneeweiss A, Denkert C, Weichert W, Trumpp A. Co-expression of MET and CD47 is a novel prognosticator for survival of luminal breast cancer patients. Oncotarget 2014; 5(18): 8147-8160

13. Nagahara M1, Mimori K, Kataoka A, Ishii H, Tanaka F, Nakagawa T, Sato T, Ono S, Sugihara K, Mori M. Correlated expression of CD47 and SIRPA in bone marrow and in peripheral blood predicts recurrence in breast cancer patients. Clin Cancer Res 2010; 16(18): 4625-4635

14. Suzuki S, Yokobori T, Tanaka N, Sakai M, Sano A, Inose T, Sohda M, Nakajima M, Miyazaki T, Kato H, Kuwano H. CD47 expression regulated by the miR-133a tumor suppressor is a novel prognostic marker in esophageal squamous cell carcinoma. Oncol Rep 2012; 28(2): 465-472

15. Yoshida K, Tsujimoto H, Matsumura K, Kinoshita M, Takahata R, Matsumoto Y, Hiraki S, Ono S, Seki S, Yamamoto J, Hase K. CD47 is an adverse prognostic factor and a therapeutic target in gastric cancer. Cancer Med 2015; 4(9): 1322-1333

16. Wang H, Tan M, Zhang S, Li X, Gao J, Zhang D, Hao Y, Gao S, Liu $\mathrm{J}$, Lin B. Expression and significance of CD44, CD47 and c-met in ovarian clear cell carcinoma. Int J Mol Sci 2015; 16(2): 3391-3404

17. Gordon SR, Maute RL, Dulken BW, Hutter G, George BM, McCracken MN, Gupta R, Tsai JM, Sinha R, Corey D, Ring AM, Connolly AJ, Weissman IL. PD-1 expression by tumour-associated macrophages inhibits phagocytosis and tumour immunity. Nature 2017; 545(7655): 495-499

18. Liu X, Kwon $\mathrm{H}, \mathrm{Li} \mathrm{Z}, \mathrm{Fu} \mathrm{YX}$. Is CD47 an innate immune checkpoint for tumor evasion? J Hematol Oncol 2017; 10(1): 12

19. Barkal AA, Weiskopf K, Kao KS, Gordon SR, Rosental B, Yiu YY, George BM, Markovic M, Ring NG, Tsai JM, McKenna KM, Ho
PY, Cheng RZ, Chen JY, Barkal LJ, Ring AM, Weissman IL, Maute RL. Engagement of MHC class I by the inhibitory receptor LILRB1 suppresses macrophages and is a target of cancer immunotherapy. Nat Immunol 2018; 19(1): 76-84

20. Riley JL. PD-1 signaling in primary T cells. Immunol Rev 2009; 229(1): 114-125

21. Fuertes Marraco SA, Neubert NJ, Verdeil G, Speiser DE. Inhibitory receptors beyond $\mathrm{T}$ cell exhaustion. Front Immunol 2015; 6: 310

22. Chen L, Han X. Anti-PD-1/PD-L1 therapy of human cancer: past, present, and future. J Clin Invest 2015; 125(9): 3384-3391

23. Riella LV, Paterson AM, Sharpe AH, Chandraker A. Role of the PD1 pathway in the immune response. Am J Transplant 2012; 12(10): 2575-2587

24. Lim SO, Li CW, Xia W, Cha JH, Chan LC, Wu Y, Chang SS, Lin WC, Hsu JM, Hsu YH, Kim T, Chang WC, Hsu JL, Yamaguchi H, Ding Q, Wang Y, Yang Y, Chen CH, Sahin AA, Yu D, Hortobagyi GN, Hung MC. Deubiquitination and stabilization of PD-L1 by CSN5. Cancer Cell 2016; 30(6): 925-939

25. Liu X, Pu Y, Cron K, Deng L, Kline J, Frazier WA, Xu H, Peng H, $\mathrm{Fu} \mathrm{YX}, \mathrm{Xu}$ MM. CD47 blockade triggers $\mathrm{T}$ cell-mediated destruction of immunogenic tumors. Nat Med 2015; 21(10): 1209-1215

26. Soto-Pantoja DR, Terabe M, Ghosh A, Ridnour LA, DeGraff WG, Wink DA, Berzofsky JA, Roberts DD. CD47 in the tumor microenvironment limits cooperation between antitumor T-cell immunity and radiotherapy. Cancer Res 2014; 74(23): 6771-6783

27. Yang L, Zhang Y. Tumor-associated macrophages: from basic research to clinical application. J Hematol Oncol 2017; 10(1): 58

28. Noy R, Pollard JW. Tumor-associated macrophages: from mechanisms to therapy. Immunity 2014; 41(1): 49-61

29. Alderton GK. Tumour immunology: turning macrophages on, off and on again. Nat Rev Immunol 2014; 14(3): 136-137

30. Zijlmans HJ, Fleuren GJ, Baelde HJ, Eilers PH, Kenter GG, Gorter A. The absence of CCL2 expression in cervical carcinoma is associated with increased survival and loss of heterozygosity at 17q11.2. J Pathol 2006; 208(4): 507-517

31. Tsutsui S, Yasuda K, Suzuki K, Tahara K, Higashi H, Era S. Macrophage infiltration and its prognostic implications in breast cancer: the relationship with VEGF expression and microvessel density. Oncol Rep 2005; 14(2): 425-431

32. Ries CH, Cannarile MA, Hoves S, Benz J, Wartha K, Runza V, ReyGiraud F, Pradel LP, Feuerhake F, Klaman I, Jones T, Jucknischke U, Scheiblich S, Kaluza K, Gorr IH, Walz A, Abiraj K, Cassier PA, Sica A, Gomez-Roca C, de Visser KE, Italiano A, Le Tourneau C, Delord JP, Levitsky H, Blay JY, Rüttinger D. Targeting tumorassociated macrophages with anti-CSF-1R antibody reveals a strategy for cancer therapy. Cancer Cell 2014; 25(6): 846-859

33. Mok S, Koya RC, Tsui C, Xu J, Robert L, Wu L, Graeber T, West BL, Bollag G, Ribas A. Inhibition of CSF-1 receptor improves the antitumor efficacy of adoptive cell transfer immunotherapy. Cancer Res 2014; 74(1): 153-161

34. Han Y, Chen Z, Yang Y, Jiang Z, Gu Y, Liu Y, Lin C, Pan Z, Yu Y, Jiang $\mathrm{M}$, Zhou $\mathrm{W}$, Cao X. Human $\mathrm{CD} 14^{+} \mathrm{CTLA}^{-} 4^{+}$regulatory dendritic cells suppress T-cell response by cytotoxic T-lymphocyte antigen-4-dependent IL-10 and indoleamine-2,3-dioxygenase production in hepatocellular carcinoma. Hepatology 2014; 59(2): 567579 
35. Komohara Y, Jinushi M, Takeya M. Clinical significance of macrophage heterogeneity in human malignant tumors. Cancer Sci 2014; 105(1): 1-8

36. Li CW, Lim SO, Xia W, Lee HH, Chan LC, Kuo CW, Khoo KH, Chang SS, Cha JH, Kim T, Hsu JL, Wu Y, Hsu JM, Yamaguchi H, Ding Q, Wang Y, Yao J, Lee CC, Wu HJ, Sahin AA, Allison JP, Yu D, Hortobagyi GN, Hung MC. Glycosylation and stabilization of programmed death ligand-1 suppresses T-cell activity. Nat Commun 2016; 7: 12632

37. Jiao S, Xia W, Yamaguchi H, Wei Y, Chen MK, Hsu JM, Hsu JL, Yu WH, Du Y, Lee HH, Li CW, Chou CK, Lim SO, Chang SS, Litton J, Arun B, Hortobagyi GN, Hung MC. PARP inhibitor upregulates PD-L1 expression and enhances cancer-associated immunosuppression. Clin Cancer Res 2017; 23(14): 3711-3720

38. Zhang J, Bu X, Wang H, Zhu Y, Geng Y, Nihira NT, Tan Y, Ci Y, Wu F, Dai X, Guo J, Huang YH, Fan C, Ren S, Sun Y, Freeman GJ, Sicinski P, Wei W. Cyclin D-CDK4 kinase destabilizes PD-L1 via Cul3(SPOP) to control cancer immune surveillance. Nature 2017; 553(7686): 91-95

39. Burr ML, Sparbier CE, Chan YC, Williamson JC, Woods K, Beavis PA, Lam EYN, Henderson MA, Bell CC, Stolzenburg S, Gilan O, Bloor S, Noori T, Morgens DW, Bassik MC, Neeson PJ, Behren A, Darcy PK, Dawson SJ, Voskoboinik I, Trapani JA, Cebon J, Lehner PJ, Dawson MA. CMTM6 maintains the expression of PD-L1 and regulates anti-tumour immunity. Nature 2017; 549(7670): 101105

40. Mezzadra R, Sun C, Jae LT, Gomez-Eerland R, de Vries E, Wu W, Logtenberg MEW, Slagter M, Rozeman EA, Hofland I, Broeks A, Horlings HM, Wessels LFA, Blank CU, Xiao Y, Heck AJR, Borst J, Brummelkamp TR, Schumacher TNM. Identification of CMTM6 and CMTM4 as PD-L1 protein regulators. Nature 2017; 549(7670): $106-110$

41. Li CW, Lim SO, Chung EM, Kim YS, Park AH, Yao J, Cha JH, Xia W, Chan LC, Kim T, Chang SS, Lee HH, Chou CK, Liu YL, Yeh HC, Perillo EP, Dunn AK, Kuo CW, Khoo KH, Hsu JL, Wu Y, Hsu JM, Yamaguchi H, Huang TH, Sahin AA, Hortobagyi GN, Yoo SS, Hung MC. Eradication of triple-negative breast cancer cells by targeting glycosylated PD-L1. Cancer Cell 2018; 33(2):187-201. e10

42. Dong H, Zhu G, Tamada K, Chen L. B7-H1, a third member of the B7 family, co-stimulates T-cell proliferation and interleukin-10 secretion. Nat Med 1999; 5(12): 1365-1369

43. Rodríguez-García M, Porichis F, de Jong OG, Levi K, Diefenbach TJ, Lifson JD, Freeman GJ, Walker BD, Kaufmann DE, Kavanagh DG. Expression of PD-L1 and PD-L2 on human macrophages is upregulated by HIV-1 and differentially modulated by IL-10. J Leukoc Biol 2011; 89(4): 507-515

44. Wu K, Kryczek I, Chen L, Zou W, Welling TH. Kupffer cell suppression of $\mathrm{CD} 8^{+} \mathrm{T}$ cells in human hepatocellular carcinoma is mediated by B7-H1/programmed death-1 interactions. Cancer Res 2009; 69(20): 8067-8075

45. Xiao Y, Yu S, Zhu B, Bedoret D, Bu X, Francisco LM, Hua P, Duke-Cohan JS, Umetsu DT, Sharpe AH, DeKruyff RH, Freeman GJ. RGMb is a novel binding partner for PD-L2 and its engagement with PD-L2 promotes respiratory tolerance. J Exp Med 2014; 211 (5): 943-959

46. Kryczek I, Zou L, Rodriguez P, Zhu G, Wei S, Mottram P, Brumlik
M, Cheng P, Curiel T, Myers L, Lackner A, Alvarez X, Ochoa A, Chen L, Zou W. B7-H4 expression identifies a novel suppressive macrophage population in human ovarian carcinoma. J Exp Med 2006; 203(4): 871-881

47. Dangaj D, Lanitis E, Zhao A, Joshi S, Cheng Y, Sandaltzopoulos R, Ra HJ, Danet-Desnoyers G, Powell DJ Jr, Scholler N. Novel recombinant human $\mathrm{b} 7 \mathrm{~h} 4$ antibodies overcome tumoral immune escape to potentiate T-cell antitumor responses. Cancer Res 2013; 73(15): 4820-4829

48. Dong J, Cheng L, Zhao M, Pan X, Feng Z, Wang D. Tim-3expressing macrophages are functionally suppressed and expanded in oral squamous cell carcinoma due to virus-induced Gal-9 expression. Tumour Biol 2017; 39(5): 1010428317701651

49. Li H, Wu K, Tao K, Chen L, Zheng Q, Lu X, Liu J, Shi L, Liu C, Wang G, Zou W. Tim-3/galectin-9 signaling pathway mediates Tcell dysfunction and predicts poor prognosis in patients with hepatitis B virus-associated hepatocellular carcinoma. Hepatology 2012; 56(4): 1342-1351

50. Yu X, Harden K, Gonzalez LC, Francesco M, Chiang E, Irving B, Tom I, Ivelja S, Refino CJ, Clark H, Eaton D, Grogan JL. The surface protein TIGIT suppresses T cell activation by promoting the generation of mature immunoregulatory dendritic cells. Nat Immunol 2009; 10(1): 48-57

51. Li M, Xia P, Du Y, Liu S, Huang G, Chen J, Zhang H, Hou N, Cheng X, Zhou L, Li P, Yang X, Fan Z. T-cell immunoglobulin and ITIM domain (TIGIT) receptor/poliovirus receptor (PVR) ligand engagement suppresses interferon- $\gamma$ production of natural killer cells via $\beta$-arrestin 2 -mediated negative signaling. J Biol Chem 2014; 289(25): 17647-17657

52. Tahara-Hanaoka S, Shibuya K, Onoda Y, Zhang H, Yamazaki S, Miyamoto A, Honda S, Lanier LL, Shibuya A. Functional characterization of DNAM-1 (CD226) interaction with its ligands PVR (CD155) and nectin-2 (PRR-2/CD112). Int Immunol 2004; 16(4): 533-538

53. Guillemin GJ, Brew BJ. Microglia, macrophages, perivascular macrophages, and pericytes: a review of function and identification. J Leukoc Biol 2004; 75(3): 388-397

54. Zhu Y, Paniccia A, Schulick AC, Chen W, Koenig MR, Byers JT, Yao S, Bevers S, Edil BH. Identification of CD112R as a novel checkpoint for human T cells. J Exp Med 2016; 213(2): 167-176

55. Galdiero M, Pisciotta MG, Gorga F, Petrillo G, Marinelli A, Galdiero E. Modulation of costimulatory molecules CD80/CD86 on B cells and macrophages by stress proteins GroEL, GroES and DnaK. Int J Immunopathol Pharmacol 2005; 18(4): 637-644

56. Zang X, Allison JP. The B7 family and cancer therapy: costimulation and coinhibition. Clin Cancer Res. 2007; 13(18 Pt 1): 52715279

57. Willingham SB, Volkmer JP, Gentles AJ, Sahoo D, Dalerba P, Mitra SS, Wang J, Contreras-Trujillo H, Martin R, Cohen JD, Lovelace P, Scheeren FA, Chao MP, Weiskopf K, Tang C, Volkmer AK, Naik TJ, Storm TA, Mosley AR, Edris B, Schmid SM, Sun CK, Chua MS, Murillo O, Rajendran P, Cha AC, Chin RK, Kim D, Adorno M, Raveh T, Tseng D, Jaiswal S, Enger PO, Steinberg GK, Li G, So SK, Majeti R, Harsh GR, van de Rijn M, Teng NN, Sunwoo JB, Alizadeh AA, Clarke MF, Weissman IL. The CD47-signal regulatory protein alpha (SIRPa) interaction is a therapeutic target for human solid tumors. Proc Natl Acad Sci USA 2012; 109(17): 
$6662-6667$

58. Wang Q, Zhang P, Zhang Q, Wang X, Li J, Ma C, Sun W, Zhang L. Analysis of CD137 and CD137L expression in human primary tumor tissues. Croat Med J 2008; 49(2): 192-200

59. Chao MP, Jaiswal S, Weissman-Tsukamoto R, Alizadeh AA, Gentles AJ, Volkmer J, Weiskopf K, Willingham SB, Raveh T, Park CY, Majeti R, Weissman IL. Calreticulin is the dominant prophagocytic signal on multiple human cancers and is counterbalanced by CD47. Sci Trans1 Med 2010; 2(63):63ra94

60. Leclerc E, Fritz G, Vetter SW, Heizmann CW. Binding of S100 proteins to RAGE: an update. Biochim Biophys Acta 2009; 1793(6): 993-1007

61. Kinouchi M, Miura K, Mizoi T, Ishida K, Fujibuchi W, Sasaki H, Ohnuma S, Saito K, Katayose Y, Naitoh T, Motoi F, Shiiba K, Egawa S, Shibata C, Unno M. Infiltration of CD40-positive tumorassociated macrophages indicates a favorable prognosis in colorectal cancer patients. Hepatogastroenterology 2013; 60(121): 83-88

62. Elgueta R, Benson MJ, de Vries VC, Wasiuk A, Guo Y, Noelle RJ.
Molecular mechanism and function of CD40/CD40L engagement in the immune system. Immunol Rev 2009; 229(1): 152-172

63. Karulf M, Kelly A, Weinberg AD, Gold JA. OX40 ligand regulates inflammation and mortality in the innate immune response to sepsis. J Immunol 2010; 185(8): 4856-4862

64. Croft M, So T, Duan W, Soroosh P. The significance of OX40 and OX40L to T-cell biology and immune disease. Immunol Rev 2009; 229(1): 173-191

65. Zhang Y, Luo Y, Qin SL, Mu YF, Qi Y, Yu MH, Zhong M. The clinical impact of ICOS signal in colorectal cancer patients. OncoImmunology 2016; 5(5): e1141857

66. Lines JL, Pantazi E, Mak J, Sempere LF, Wang L, O’Connell S, Ceeraz S, Suriawinata AA, Yan S, Ernstoff MS, Noelle R. VISTA is an immune checkpoint molecule for human $\mathrm{T}$ cells. Cancer Res 2014; 74(7): 1924-1932

67. Nowak EC, Lines JL, Varn FS, Deng J, Sarde A, Mabaera R, Kuta A, Le Mercier I, Cheng C, Noelle RJ. Immunoregulatory functions of VISTA. Immunol Rev 2017; 276(1): 66-79 